\title{
Relationship between haemolymphatic levels of juvenile hormone and the duration of the spermatophore in the bursa copulatrix of the cockroach Blaberus craniifer Burm.
}

\author{
F. Goudey-Perrière ${ }^{1}$, J.C. Baehr ${ }^{2}$ and P. Brousse-Gaury ${ }^{1}$ \\ 1 Laboratoire de biologie animale appliquée et centre de biologie de l'insecte, centre d'études \\ pharmaceutiques, université de Paris Sud, F-92290 Châtenay-Malabry; \\ 2 Laboratoire de biologie animale, université de Poitiers, 40 avenue du Recteur Pineau, F-86022 \\ Poitiers Cédex, France
}

(received 21 June, 1988; accepted 12 May, 1989)

Summary - In Blaberus craniffer females, fecundation is not required for oviposition. However, during the first gonadotrophic cycle, oviposition occurs about $1 \mathrm{wk}$ earlier in mated females. As ovarian activity is essentially under the control of juvenile hormone $(\mathrm{JH})$, haemolymphatic hormone levels were measured by radioimmunoassay in both virgin and mated females. In the latter, the duration of the spermatophore in the bursa copulatrix was manipulated.

Matings were performed with single pairs : a 7-day-old virgin female was allowed to mate with a virgin male, and the spermatophore was extirpated from the bursa copulatrix just after completion of mating, or $24 \mathrm{~h}$ after pairing. The females were then isolated, and $\mathrm{JH}$ levels were measured from the 8 th to the 12 th post-imaginal day.

The results show that the haemolymphatic level of $\mathrm{JH}$ (JH III) remained low in virgin females for $12 \mathrm{~d}$ after the imaginal molt $(<16 \mathrm{ng} / \mathrm{ml})$. The juvenile hormone titre following mating was higher when the spermatophore was left in the bursa for around $22 \mathrm{~h}$ after copulation, reaching a peak of $239 \mathrm{ng} / \mathrm{ml}$. The longer the spermatophore remained in the bursa copulatrix, the sooner oviposition took place.

The results show for the first time that there is a relationship between the duration of the spermatophore in the bursa copulatrix and haemolymphatic levels of juvenile hormone and basal oocyte growth during the first gonadotrophic cycle. The stimulating effect of the spermatophore from the bursa is discussed.

mating - gonadotrophic cycle - JH III - oocyte growth - oviposition - cockroach Blaberus craniifer

Résumé - Taux hémolymphatique d'hormone juvénile et temps de présence du spermatophore dans la bourse copulatrice de la blatte Blaberus craniffer Burm. Chez les femelles de la Blatte ovovivipare Blaberus craniifer, la fécondation n'est pas indispensable à l'oviposition. Cependant, la première oviposition se produit environ une semaine plus tôt chez les femelles inséminées. L'activité ovarienne étant contrôlée par l'hormone juvénile (JH), nous avons comparé par dosage radio-immunologique (R.I.A.) les taux hémolymphatiques d'hormone juvénile chez les femelles, vierges ou non. Dans ce dernier cas, nous avons pris en compte la présence plus ou moins prolongée du spermatophore dans la bourse copulatrice. Dans les expériences, une femelle vierge de 7 jours a été appariée avec un mâle vierge. Le spermatophore a été extirpé de la bourse copulatrice immédiatement après la séparation des partenaires sexuels ou 24 heures après 
leur mise en présence. Les femelles ont alors été isolées et les dosages effectués du $8^{\theta}$ au $12^{\circ}$ jour de la vie imaginale.

Les résultats montrent que le taux hémolymphatique d'hormone juvénile (JH III) reste bas chez les femelles vierges durant les 12 premiers jours de vie imaginale : il n'excède pas $16 \mathrm{ng} / \mathrm{ml}$. Son augmentation, après l'accouplement, est d'autant plus importante que le spermatophore séjourne plus longtemps (environ 22 h dans nos expériences) dans les voies génitales de la fermelle : le maximum est de $239 \mathrm{ng} / \mathrm{ml}$ dans les expérimentations. L'oviposition est significativement plus précoce quand le spermatophore reste dans la bourse.

Les données expérimentales établissent, pour la première fois, des corrélations positives entre la présence prolongée du spermatophore dans la bourse copulatrice, le taux d'hormone juvénile circulante et la croissance des ovocytes terminaux, au cours du premier cycle ovarien. Cet effet stimulateur du spermatophore, à partir de la bourse, est discuté.

\section{copulation - cycle gonadotrophique - JH III - croissance des ovocytes - oviposition - blatte - Blaberus craniifer}

\section{Introduction}

Ovarian maturation in cockroaches is essentially controlled by the corpora allata (CA) (Engelmann, 1970) along with various external factors which include the stimuli associated with mating (Roth, 1970). Although the effects of mating may differ between species, in most cases mating activates the CA (Buhimann, 1976; Lanzrein et al., 1980), optimizes the timing of ovulation (Engelmann, 1960; Roth and Stay, 1962; Goudey-Perrière, 1987), accelerates oocyte growth (Roth and Stay, 1961; 1962; Roth, 1970), and enhances female fecundity (Griffiths and Tauber, 1942.). Oocyte growth in virgins of Blaberus craniifer Burm. (= B. fusca Br.) during the first gonadotrophic cycle is rapid (Roth and Stay, 1962; BrousseGaury, 1972; Brousse-Gaury and Cassier, 1975); mating is not required for completion of oocyte development, but will induce oviposition one week earlier than in virgin females. In experiments with single pairs $\left(1 \sigma^{\prime}+19\right)$, where matings were not taken into account, oocyte maturation during the first preoviposition period has been found to be associated with cyclic changes in the cellular nuclear ration in the CA (Brousse-Gaury, 1972).
These changes are less pronounced in virgin females. This was thought to indicate reduced CA activity, demonstrated by a slower oocyte growth rate, and a smaller oocyte at ovulation (BrousseGaury, 1972). These effects were attributed to the absence of mating stimuli. The present investigation was directed towards understanding the effect of the spermatophore on $\mathrm{JH}$ levels in haemolymph, in relation to the time the spermatophore stays in the bursa copulatrix. The presence of large quantities of ecdysteroids in maturing basal oocytes (Bullière et al., 1979) has suggested that these hormones may play a role in the regulation of $\mathrm{JH}$ (as in Diploptera punctata : Stay et al., 1980). Our experiments were thus carried out during the first gonadotrophic cycle, prior to the increase in ecdysteroids levels in haemolymph which is observed at $14 \mathrm{~d}$ in Blaberus craniifer (Bullière et al., 1979).

\section{Materials and Methods}

Blaberus craniifer were reared according to previously described methods (Goudey- 
Perrière and Brousse-Gaury, 1982). Adults were collected from the colonies at ecdysis (day $0=\mathrm{D} 0$ ). Males from an insectary, fed and kept crowded under ambient laboratory conditions for $2-3 \mathrm{mo}$, were used for the mating tests. These virgin males constituted an homogeneous group since they mated with receptive females within a few minutes, copulation lasted about $2 \mathrm{~h}$ and their first spermatophore was normally well formed. Females were isolated at the imaginal moult. They were housed individually in boxes, with access to food ad libitum and tested when 7 days old. Previous observations have demonstrated that, by that time, females display sexual activity and mate within about 5 min (Goudey-Perrière and Brousse-Gaury, 1982; Goudey-Perrière, 1987).

Three sets of experiments were carried out : virgin females in isolation as controls (Exp 1, 123 females); 7-day-old females successfully mated, with spermatophore and the males removed either just after completion of mating (Exp 2, 170 females), or $24 \mathrm{~h}$ after pairing (Exp 3, 160 females). Every day between do and d12, in each series of experiments, some females (most often the same animals) were used for assay of $\mathrm{JH}$ and examination of oocytes. The others provided a baseline for the occurrence of oviposition (Table I).

Haemolymph $(15-30 \mathrm{mg} / \mathrm{female})$ was collected atter removal of the legs, antennae and cerci. In each set of experiments (79 $\% / 80$ in $\operatorname{Exp} 1,32 \% / 33$ in $\operatorname{Exp} 2$, and $30 \% / 33$ in Exp 3) and for each point, $\approx 200 \mathrm{mg}$ of haemolymph from insects of the same age were pooled and stored at $-30^{\circ} \mathrm{C}$ in $2 \mathrm{ml}$ of a mixture of methanol/diethyl ether (1/1). 3000 dpm of [3H] JH III $(10 \mathrm{Ci} / \mathrm{mmol}$, New England Nuclear) were added to the haemolymph to evaluate recovery (JH lost $+\mathrm{JH}$ breakdown). $\mathrm{JH}$ III was extracted and purified as described in Baehr et al. $(1979,1981)$ and Poras et al. (1983). Briefly, JH III was extracted by phase

Table I. JH III haemolymph levels, length of terminal oocyte and age of females when ovipositing (first gonadotrophic cycle).

Virgin females

\begin{tabular}{lrl} 
& & \\
\cline { 2 - 3 } Day & \multicolumn{1}{l}{$\begin{array}{l}J H I I \\
(n g / m l)\end{array}$} & $\begin{array}{l}\text { oocyte } \\
(\mathrm{mm})\end{array}$ \\
& & \\
& & \\
0 & $4.8(3)$ & $1.44 \pm 0.06(3)$ \\
1 & $5.8(5)$ & $1.61 \pm 0.06(5)$ \\
2 & $16.0(4)$ & $1.73 \pm 0.18(4)$ \\
3 & $7.5(5)$ & $1.62 \pm 0.14(5)$ \\
4 & $7.3(6)$ & $1.91 \pm 0.25(6)$ \\
5 & $10.3(7)$ & $2.17 \pm 0.27(7)$ \\
6 & $3.2(7)$ & $2.56 \pm 0.50(7)$ \\
7 & $10.3(8)$ & $3.16 \pm 0.50(6)$ \\
8 & $10.7(6)$ & $2.86 \pm 0.19(4)$ \\
9 & $8.7(8)$ & $3.82 \pm 0.30(7)$ \\
10 & $6.9(7)$ & $3.47 \pm 0.60(4)$ \\
11 & $7.0(7)$ & $3.30 \pm 0.29(4)$ \\
12 & $10.0(6)$ & $4.16 \pm 0.30(7)$ \\
& &
\end{tabular}

Mated females; spermatophore removed

\begin{tabular}{|c|c|c|c|}
\hline \multicolumn{2}{|c|}{$\begin{array}{c}\text { Immediately after } \\
\text { copulation }\end{array}$} & \multicolumn{2}{|c|}{24 hrs after pairing } \\
\hline $\begin{array}{l}J H I I I \\
(n g / m l)\end{array}$ & $\begin{array}{l}\text { oocyte } \\
(\mathrm{mm})\end{array}$ & $\begin{array}{l}J H I I I \\
(n g / m l)\end{array}$ & $\begin{array}{l}\text { oocyte } \\
(\mathrm{mm})\end{array}$ \\
\hline
\end{tabular}

Age at

$17.2(7) \quad 3.39 \pm 0.14(4)$

$21.1(8) \quad 3.96 \pm 0.51(8)$

$13.6(7) \quad 3.75 \pm 0.58(5)$

$30.1(6)$

$3.63 \pm 0.98(5)$

41.0 (4)
$46.1(6)$

$24.9(6) \quad 4.64 \pm 0.33(3)$

$238.7(6) \quad 4.44 \pm 0.76(7)$

$142.0(6) \quad 5.09 \pm 0.22(2)$

(day) 
partition in pentane and purified by silica column chromatography (Seppak C18, Waters S.A.) followed by high pressure liquid chromatography (HPLC) (Radial Pak Cn $5 \mathrm{~mm}$, Waters S.A.) using methanol/water $(40 / 60)$ as the mobile phase. $\mathrm{JH}$ was quantified in the HPLC fractions by radioimmunoassay (RIA) using specific antisera and iodinated tracers. With a JH Ill-specific RIA system, positive immunoreactivity was only detected in fractions containing JH III.

Dilution and addition tests were positive. The data were expressed as JH III equivalent immunoreactive material in $\mathrm{ng} / \mathrm{ml}$ of haemolymph ( $1 \mathrm{ml}=1 \mathrm{~g})$ after correction for recovery.

After removal of haemolymph, basal oocyte length in 0 to 12-day-oid females was measured (on $69 \% / 80$ insects in Exp 1,27 $\%$ / 33 in Exp 2 and $26 \% / 33$ in Exp 3); the mean length of all basal oocytes was calculated in each female, and a new mean was established for each group of females at a given age (Table I). Standard errors were calculated. Wilcoxon's rank test was used to compare the paired groups.

In the remaining females, the presence of ootheca was checked after $\mathrm{d} 13$ by examination of the bursa copulatrix twice a day. For each experiment $(43,137$ and 127 females for Exp 1,2 and 3 , respectively), the age at oviposition was recorded and the results analysed by Student's t-test.

\section{Results}

In virgin females Blaberus craniifer, JH III was detected at the beginning of imaginal life $(4.8 \mathrm{ng} / \mathrm{ml})$ and remained low (around $10 \mathrm{ng} / \mathrm{ml}$ ) during the observation period (D0 - D12). The maximum (16 $\mathrm{ng} / \mathrm{ml})$, was observed at D2 (i.e. at the onset of vitellogenesis). After mating on D7, the JH III level rose, although two patterns of increase were observed depending on the duration of the spermatophore in the bursa copulatrix. In Exp 2, the rise in $\mathrm{JH}$ titre was slower, and did not exceed 41 $\mathrm{ng} / \mathrm{ml}$ by $\mathrm{D12}$. In contrast, in Exp 3 , the rise was much faster and more intense, reaching $240 \mathrm{ng} / \mathrm{ml}$ by $\mathrm{d} 11$.

At emergence, basal oocytes were about $1.4 \mathrm{~mm}$ in length. They grew in virgin females to a length of $4.2 \pm 0.3 \mathrm{~mm}$ by $\mathrm{d} 12$. The changes between D2- D3, D7-D8 and D9-D11 were not statistically significant. Similar observations were made on the mated females between D9-D11 (Exp 2) or D10-D11 (Exp 3). At D12 they reached $4.7 \pm 0.7$ $\mathrm{mm}$ in Exp 2, and $5.1 \pm 0.2 \mathrm{~mm}$ in Exp 3 . There was a significant difference in oocyte length between the three experiments, with the growth of the basal oocyte closely paralleling the haemolymphatic JH III level.

The age at oviposition provided a suitable control for these correlations : oviposition occurred earlier in the mated females than in the virgins $(16.1 \pm 0.5$ and $19.2 \pm 0.7$ days vs $22.7 \pm 1$; cf 3 vs $1, P<$ $10^{-12} ; 2$ vs $1, P<10^{-8}$ ). There was also a significant difference in oviposition dates between the females in experiments 3 and $2\left(P<10^{-10}\right)$, demonstrating the stimulatory effect of the duration of the spermatophore in the bursa copulatrix on ovarian maturation.

With respect to the RIA results (Table I), expressed as $\mathrm{ng} \mathrm{JH}$ III equivalent per $\mathrm{ml}$ haemolymph, two main observations were made. First, JH III was detectable in the haemolymph of virgin females for the first 7 days following adult emergence. Second, in 7-day-old mated females, there was a peak in the haemolymph $\mathrm{JH}$ titre.

\section{Discussion}

In Leucophae maderae (F.) (Koeppe et al., 1980), JH was undetectable in the 
haemolymph of virgin females for the first 8 days post-emergence, and mating induced an increase in the $\mathrm{JH}$ level (peak at $16.44 \mathrm{ng} / \mathrm{ml}$ by D12), while in Diploptera punctata (Eschscholtz) (Tobe et al., 1985), the JH III titre increased after mating, reaching $1600 \mathrm{ng} / \mathrm{ml}$ by D5.

Our data confirm the effect of mating on $\mathrm{JH}$ titre in Blaberus craniifer, but also indicate for the first time, that the duration of the spermatophore in the bursa copulatrix also has a significant influence on $\mathrm{JH}$ titre in this species in which vitellogenesis occurs in virgin females with no concomitant increase in $\mathrm{JH}$ levels.

However, in $B$. craniifer, it is not clear whether JH levels were solely controlled by activity of the CA, as is thought to be the case in both Diploptera punctata (Stay and Tobe, 1978; Tobe and Stay, 1980) and Nauphoeta cinerea (Lanzrein et al., 1981). JH levels were also dependant on hormone breakdown (De Kort and Granger, 1981; Tobe and Stay, 1985). In addition, in Diploptera punctata (Tobe et al., 1985), a non-haemolymph pool of $\mathrm{JH}$ was suspected.

In the adult female Diploptera punctata, $\mathrm{JH}$ biosynthesis was related to the number of cells in the CA, which increased after mating (Tobe et al., 1984). The stimulus of mating resulted in a characteristic cycle of $\mathrm{JH}$ production, later stimulating oocyte growth. The effects of the different parts of the mating sequence on the biosynthesis of $\mathrm{JH}$ by the $\mathrm{CA}$ have only been studied indirectly from their influence on oocyte development. In Diploptera punctata (Engelmann, 1960; Roth and Stay, 1961), as well as in Nauphoeta cinerea (Roth, 1964), copulation prior to spermatophore transfer or prior to the firm insertion of the spermatophore into the bursa was a relatively poor stimulus for oocyte maturation.
This observation emphasizes the importance of the spermatophore, after completion of mating, in the activation of the $\mathrm{CA}$. It has also been found that insertion of an artifical glass spermatophore in the bursa copulatrix of virgin female Diploptera punctata results in activation of the CA with subsequent yolkdeposition in the oocytes (Engelmann, 1959).

In Blaberus craniifer, there is evidence for mecano- and chemoreceptors in the bursa (Brousse-Gaury, 1974) which may detect the presence of the spermatophore. Manual insertion of a glass spermatophore or a dried spermatophore, however, does not produce the full effects of a real spermatophore. Even when a true spermatophore with its glue-like secretion is properly transferred to a virgin female, the natural evolution of the chemical properties of the spermatophore in situ may not be accurately reproduced since :

- a spermatophore will only induce vitellogenesis in an imaginal molt decapitated female if it is removed from the bursa some hours after completion of mating (Brousse-Gaury and GoudeyPerrière, 1983; Baehr et al., 1983);

- topical application of acetone extracts of spermatophore taken at this time leads to earlier oviposition in virgin females (Goudey-Perrière, 1987). However, JH does not appear to be responsible for this activity (Baehr et al., 1983);

- enzymatic activities in Blaberus craniifer spermatophore alter during the 3 post-mating days (Perrière and GoudeyPerrière, 1988).

The change in the chemical properties of the spermatophore of Blaberus craniifer in situ may explain the long-term effect of the spermatophore. There is a close relationship between the duration of the spermatophore in the bursa and $\mathrm{JH}$ titre and subsequent oocyte growth. 
A nervous mechanism from sense organs in the bursa may play a role, with stimuli being transmitted via the ventral nerve cord to the brain (Grillou, 1971) which innervates the CA (Brousse-Gaury, 1971). The effects of transection of the nerve cord after mating has not been studied in Blaberus craniifer. However, in Leucophaea maderae, the full mating effect on ovulation is only observed if the ventral nerve cord of the female remains intact for at least 2 days after copulation (Engelmann, 1960). In cockroaches, these effects have been attributed to a loss of nervous stimuli, rather than to a loss of neuroendocrine stimuli. Such studies will require confirmation, since neurosecretory cells are present in the ventral nerve cord in both Leucophaea maderae (De Bessé, 1967) and Blaberus craniifer (Geldiay, 1959), and, therefore, the involvement of neuroendocrine factors from the nerve cord in the regulation of oocyte growth cannot, therefore, be ruled out.

In conclusion, in Blaberus craniifer, the level of $\mathrm{JH}$ in haemolymph is influenced both by the presence and the duration of the spermatophore in the bursa copulatrix. It seems likely that this is due to tactile and chemical stimulation from the spermatophore in the bursa, transmitted via the ventral nerve cord to the brain and the CA. Thus the spermatophore enhances oocyte growth via an action on $\mathrm{JH}$. However, the spermatophore of Blaberus craniifer may also act on the onset of vitellogenesis independently of the CA. Whether the effect is translated in decapitated Blaberus craniifer females by a vitellotropic spermatophore factor, a nonhaemolymphatic JH pool, and/or neurohormones remains to be determined.

Whatever the mechanism in Blaberus craniifer, residence of the spermatophore in the bursa copulatrix is required for full expression of the mating stimulus on ovarian development.

\section{References}

Baehr J.C., Brousse-Gaury P., Goudey-Perrière F. (1983) Essai de caractérisation d'un facteur vitellotrope dans le spermatophore de Blabera fusca Br. (Dictyoptère, Blaberidae). C.R. Acad. Sci. 297, 511-514

Baehr J.C., Caruelle J.P., Porcheron P. \& Cassier P. (1981) Quantification of juvenile hormone using a radioimmunological assay in the analysis of biological samples. In : Juvenile Hormone Biochemistry (G.E. Pratt \& G.T. Brooks, eds.), Elsevier, Amsterdam, p. 47

Baehr J.C., Pradelles P. \& Dray F. (1979) A radioimmunological assay for naturally occuring insect juvenile hormones using iodinated tracers : its use in the analysis of biological sample. Ann. Biol. Anim. Biochim. Biophys. 19, 1827-1836

Brousse-Gaury P. (1971) Influence de stimuli externes sur le comportement neuroendocrinien de Blattes. Ann. Sci. Nat. Zool. Biol. Anim. $12^{\mathrm{e}}$ sér. $13,181-332$

Brousse-Gaury P. (1972) Influence de stimuli externes sur le comportement neuroendocrinien de Blattes. III. Stimuli externes et corrélations allato-gonadotropes. Ann. Sci. Nat. Zool. Biol. Anim., $12^{e}$ sér. 14, 445-584

Brousse-Gaury P. (1974) La bourse copulatrice de Blattes ovovivipares, point d'impact de stimuli mécaniques et chimiques. Bull. Biol. 108, 3-30

Brousse-Gaury P. \& Cassier P. (1975) Contribution expérimentale et infra-structurale à l'étude de la dynamique des corpora allata chez Blabera fusca. Influence du jeûne, du groupement et du régime photopériodique. Bull. Biol. 109, 253-277

Brousse-Gaury P. \& Goudey-Perrière F. (1983) Spermatophore et vitellogenèse chez Blabera fusca (Dictyoptère, Blaberidae). C.R. Acad. Sci. 296, 659-664

Buhimann G. (1976) Haemolymph vittellogenin, juvenile hormone, and oocyte growth in the adult cockroach Nauphoeta cinerea during first pre-oviposition period. J. Insect Physiol. 22, $1101-1110$ 
Bullière D., Bullière F. \& De Reggi M. (1979) Ecdysteroid titres during ovarian and embryonic development in Blaberus craniffer. Wilhelm Roux's Arch. Dev. Biol. 186, 103-114

De Bessé N. (1967) Neurosécrétion dans la chaîne nerveuse ventrale de deux Blattes, Leucophaea maderae (F.) et Periplaneta americana (L.). Bull. Soc. Zool. Fr. 92, 73-86

De Kort C.A.D. \& Granger N.A. (1981) Regulation of the juvenile hormone titer. Annu. Rev. Entomol. 26, t-28

Engeimann F. (1959) The control of reproduction in Diploptera punctata. Biol. Bull. 116, 406-419

Engelmann F. (1960) Mechanisms controlling reproduction in two viviparous cockroaches (Blattaria). Ann. N.Y. Acad. Sci. 89, 516-536

Engelmann F. (1970) The Physiology of insect Reproduction. International Series of Monographs in Pure and Applied Biology, vol. 44, Pergamon Press, Oxford, New York

Geldiay S. (1959) Neurosecretory cells in ganglia of the roach Blaberus craniifer. Biol. Bull. 117, 267-274

Goudey-Perrière F. (1987) Socialité, sexualité et reproduction chez Blabera craniifer Burm. Thèse ès Sciences, Paris VI, p. 358

Goudey-Perrière F. \& Brousse-Gaury P. (1982) Jeûne et aptitudes sexuelles des femelles de Blabera fusca $\mathrm{Br}$. (Dictyoptera, Blaberidae) en début de vie imaginale. Ann. Sci. Nat. Zool. Biol. Anim. $13^{\theta}$ série, 4, 127-151

Griffiths J.T. \& Tauber E.O. (1942) Fecundity, longevity and parthenogenesis of the american roach, Periplaneta americana L. Physiol. Zool. 15, 196-209

Grillou H. (1971) Etude de quelques-uns des facteurs du contrôle de la réceptivité sexuelle chez Blabera craniifer Burm. (Blattaria). Thèse $3^{\theta}$ cycle, Rennes, p. 71

Koeppe J.K., Brantley S.G. \& Nijhout M.M. (1980) Structure, haemolymph titre, and regulatory effects of juvenile hormone during ovarian maturation in Leucophaea maderae. $J$. Insect Physiol. 26, 749-753

Lanzrein B., Wilhem R. \& Buschor I. (1981) On the regulation of the corpora allata activity in adult females of the ovoviviparous cockroach Nauphoeta cinerea. In : Juvenile Hormone Biochemistry (G.E. Pratt \& G.T. Brooks, eds.), Elsevier, Amsterdam, 147-160

Lanzrein B., Wilhem R. \& Gentinetta V. (1981) On relations between corpus allatum activity and oocyte maturation in the cockroach Nauphoeta cinerea. Int. Conf. on Regulation of
Insect Development and Behaviour 1980, Wroclav Technical Press, Wroclav, Poland, Part II, pp. 523-534

Perrière C. \& Goudey-Perrière F. (1988) Activités enzymatiques dans le spermatophore de la Blatte ovovivipare Blaberus craniifer Burm. (Dictyoptère, Blaberidae, Blaberinae). Bull. Soc. Zool. Fr. 113, 401-413, 450-451

Poras M., Baehr J.C. \& Cassier P. (1983) Control of corpus allatum activity during the imaginal diapause in females of Locusta migratoria L. Int. J. Invertebr. Reprod. 6, 111122

Roth L.M. (1964) Control of reproduction in female cockroaches with special reference to Nauphoeta cinerea. I. First pre-oviposition period. J. Insect Physiol. 10, 915-945

Roth L.M. (1970) The stimuli regulating reproduction in cockroaches. Coll. Int. CNRS 189, 267-288

Roth L.M. \& Stay B. (1961) Oocyte development in Diploptera punctata (Eschscholtz) (Blattaria). J. Insect Physiol. 7, 186-202

Roth L.M. \& Stay B. (1962) A comparative study of oocyte development in false ovoviparous cockroaches. Psyche 69, 165-208 Stay B. \& Tobe S.S. (1978) Control of juvenile hormone biosynthesis during the reproductive cycle of a viviparous cockroach. II. Effects of unilateral allatectomy, implantation of supernumerary corpora allata and ovariectomy. Gen. Comp. Endocrinol. 34, 276-286

Stay B., Tobe S.S. \& Mundall E.C. (1980) Feedback control of juvenile hormone synthesis in cockroaches : possible role for ecdysterone. Science 207, 1827-1836

Tobe S.S., Clarke N., Stay B. \& Ruegg R.P. (1984) Changes in cell number and activity of the corpora allata of the cockroach Diploptera punctata : a role for mating and the ovary. Can. J. Zool. 62, 2178-2182

Tobe S.S., Ruegg R.P., Stay B., Baker F.C., Miller C.A. \& Schooley D.A. (1985) Juvenile hormone titre and regulation in the cockroach Diploptera punctata. Experientia 41, 1028-1034

Tobe S.S. \& Stay B. (1980) Control of juvenile hormone biosynthesis during the reproductive cycle of a viviparous cockroach. III. Effects of denervation and age on compensation with unilateral allatectomy and supernumerary corpora allata. Gen. Comp. Endocrinol. 40, 8998

Tobe S.S. \& Stay B. (1985) Structure and regulation of the corpus allatum. Adv. Insect Physiol. 18, 306-432 